MINERALOGIA POLONICA

DOI 10.2478/v10002-007-0009-6

PL ISSN 0032-6267

Vol. 37, No 2, 2006

\title{
Centenary of the birth of Professor Andrzej Bolewski (1906-2002)
}

Professor Andrzej Bolewski was born on 17 July 1906 in Małogoszcz near Kielce in south-central Poland. He graduated in 1930 from the Academy of Mining in Cracow where he had been assistant to the Chair of Mineralogy and Petrography since 1928. On

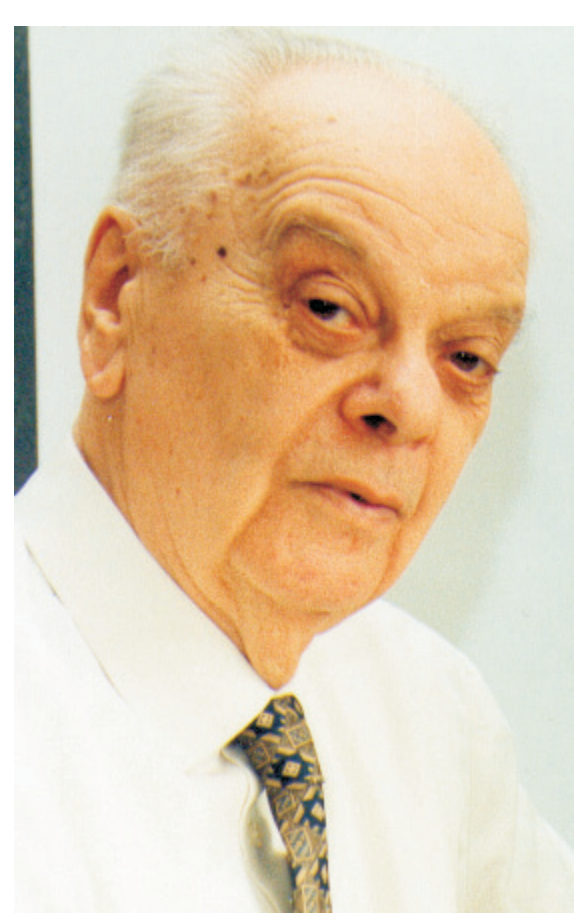
graduation, he first investigated the sulphur deposits near Cracow and visited oil deposits in Rumania, sulphur mines in Sicily, zinc and lead deposits in Greece and pyrite mines in Spain. After additional mineralogical studies in France and Belgium, Professor Andrzej Bolewski carried out petrographic studies on hard coals, phosphorites, clay raw materials and other sedimentary and magmatic rocks.

Professor Bolewski took part, as an officer, in the tragic September 1939 campaign in Poland and on 6 November 1939 was arrested, together with other academic teachers from the Cracow universities, in the Sonderaktion Krakau taken against Polish intellectuals. After release from imprisonment in the Nazi concentration camps of Sachsenhausen and $\mathrm{Da}-$ chau, he returned to Cracow and took part, during the Nazi occupation of 1939-1945, in the clandestine activities of his parent University, about which he wrote later several books.

During the war, Professor Bolewski was already developing a programme for the utilization of the mineral deposits in eastern Germany. Consequently, in 1945, he took part as an expert and adviser to the Polish Government in the delineation of the western frontier of Poland at the Potsdam Conference. He described his experiences in autobiographic books entitled "In the road to Potsdam" $(1977,1987)$ and "My life - my work" (1996). He also wrote important works on martyrdom and the losses of Polish scientists during World War II.

Throughout his life, Professor Bolewski was associated with the Academy of Mining and Metallurgy in Cracow. It was there that he obtained the degrees of doctor (1935), docent (1939) and professor (1946). In the years 1945-1976, he was the head of the Chair of Mineralogy and Petrography of his parent university and is considered to have 
been the founder not only of the Cracow mineralogical school, but also of modern mineralogy in Poland after World War II. During the years 1952-1957, he was the first president (with the rank of Minister) of the Central Office of Geology.

Professor Bolewski wrote or co-authored several academic handbooks of petrography and of economic geology but, primarily, of excellent modern manuals of general and descriptive mineralogy. As an expert in this field, he was for many years (1960-1987) an influential Polish representative in the Commission on New Minerals and Mineral Names of the International Mineralogical Association.

Professor Bolewski was an academic teacher of distinction who promoted 23 professors from among his pupils and successors. He was especially interested in economic geology and encouraged exploration for mineral deposits and development of mines necessary for the restoration of our country after the heavy destructions of the war. In addition, he was editor of the "Encyclopedia of Mineral Raw Materials" and co-editor of the series "Mineral Raw Materials of the World".

Professor Bolewski was an excellent promoter of scientific organizations. Among his significant achievements, one must emphasize his contribution to the formation of the Commission on Mineralogical Sciences and the Commission on Geological Sciences, both affiliated to the Cracow Branch of the Polish Academy of Sciences (1964), and of the Mineralogical Society of Poland (1969). He was the first President and honorary member of the Mineralogical Society and the first chief editor of the Transactions of the aforementioned Commissions and of Mineralogia Polonica, the official organ of the Mineralogical Society.

Among his several hundred publications on various mineralogical and geological problems, there are about fifty books and papers devoted to the history of geosciences. Thus, not surprisingly, Professor Bolewski was a senior Polish member of the International Commission on the History of Geological Sciences. He was, in addition, a member of the British and French Mineralogical Societies.

Professor Bolewski's exceptional abilities were greatly appreciated by both academic and state authorities. He was an honorary doctor of his parent Academy of Mining and Metallurgy (1984) and of the Silesian Polytechnic University (1984). Moreover, he was awarded the Order Polonia Restituta ( $1^{\text {st }}$ class) and numerous other decorations. Professor Bolewski was a fellow of the Polish Academy of Sciences (1952) and of the Section of Natural Sciences of the Polish Academy of Arts and Sciences (1990).

After long and fruitful life, working to the very end, Professor Andrzej Bolewski died on 29 October 2002 in Cracow. He was buried in the presence of representatives of Polish academic and geological institutions and of many former pupils and co-workers at the monumental Rakowice Cemetery in this royal town. 